\title{
Efficient Agrobacterium tumefaciens-mediated transformation of Malus zumi (Matsumura) Rehd using leaf explant regeneration system
}

\author{
$\operatorname{Jin} \mathrm{Xu}^{*}$ \\ Center for Agricultural Resources Research \\ Institute of Genetic and Developmental Biology \\ Chinese Academy of Sciences \\ Shijiazhuang 050021, China \\ Tel: 8631185871745 \\ Fax: 8631185815093 \\ E-mail: xujin@sjziam.ac.cn \\ Yu Zhen Wang \\ Center for Agricultural Resources Research \\ Institute of Genetic and Developmental Biology \\ Chinese Academy of Sciences \\ Shijiazhuang 050021, China \\ Tel: 8631185871756 \\ Fax: 8631185815093 \\ E-mail: wangyz_sjz@163.com \\ Heng Xia Yin \\ Center for Agricultural Resources Research \\ Institute of Genetic and Developmental Biology \\ Chinese Academy of Sciences \\ Shijiazhuang 050021, China \\ Tel: 8631185871745 \\ Fax: 8631185815093 \\ E-mail: yinhengxia@163.com

\section{Xiao Jing Liu*} \\ Center for Agricultural Resources Research \\ Institute of Genetic and Developmental Biology \\ Chinese Academy of Sciences \\ Shijiazhuang 050021, China \\ Tel: 8631185871748 \\ Fax: 8631185815093 \\ E-mail: xjliu@ms.sjziam.ac.cn
}

Financial support: The research was supported by the Knowledge Innovation Program of the Chinese Academy of Sciences (Grant no. 0707013603)

Keywords: Agrobacterium tumefaciens, apple rootstock, genetic transformation.

Abbreviations: BA: Benzylaminopurine

CTAB: Hexadecyltrimethylammonium bromide

DM-Km: Callus initiation and shoot differentiation medium with carbenicillin and kanamycin.

IDM: Callus initiation and shoot differentiation medium

IDM-Cb: Callus initiation and shoot differentiation medium with carbenicillin

LH: Lactalbumin hydrolysate

MS medium: Murashige and Skoog medium

NAA: $\alpha$-Naphthaleneacetic acid

NAA: 1-Naphthaleneacetic acid

PCR: Polymerase Chain Reaction

PGR: Plant Growth Regulators

Malus zumi is known as an excellent dwarfing apple rootstock occurring in natural or arid/semiarid soil or salina. Gene manipulation of $M$. zumi through transgenic technology can modify plant feature for further improvement fruit tree production by grafting the scion on a transgenic rootstock. Here, we report the establishment of an efficient, in vitro, shoot regeneration system and Agrobacterium tumefaciens- mediated transformation from the leaf explants for Malus zumi (Matsumura) Rehd. Leaf explants were infected with

*Corresponding authors 
Agrobacterium strains containing nptII and gus gene. The highest frequency of shoot regeneration was obtained on MS medium containing $500 \mathrm{mg} \mathrm{l}^{-1}$ Lactalbumin hydrolysate, $30 \quad \mathrm{~g}^{-1}$ fructose, supplemented with $3.0 \mathrm{mg} \mathrm{l}^{-1}$ BA, $0.2 \mathrm{mg} \mathrm{l}^{-1}$ NAA.Using fructose instead of sucrose significantly increases the shoot regeneration and decreases vitrification. This regeneration procedure was incorporated into an Agrobacterium-mediated transformation procedure in M. zumi. Kanamycin was an efficient selective agent for selection. Pre-selection (5 days after co-cultivation) improved the transformation efficiency. The emergence of expected bands by PCR analysis and Southern blot in transgenic plantlets confirmed the transformation of foreign DNA into plant genome.

Malus zumi is known as an important apple rootstock occurring in natural or arid/semiarid soil or salina (Scheewe and Ketzel, 1994). Its ability to survive in vitro on the medium of $\mathrm{pH}$ 3-8 or in soil containing the high salt concentration $\left(6 \mathrm{~g} \mathrm{l}^{-1}\right)$ without any harmful effects make this plant an excellent dwarfing rootstock for apple trees (Xu et al. 2008). In past years, the genetic improvement of Malus species has been mainly achieved by conventional plant breeding methods. Plant breeders have recombined the desired genes from fruit tree varieties and related species by sexual hybridization, and developed new cultivars with the desirable traits such as fruit quality and resistance to diseases, insects and pests. In recent years, the adoption of new technologies such as plant tissue culture and recombinant DNA have advanced and opened a new avenue for fruit tree improvement (Mohan Jain, 2001; Faheem et al. 2008), which can shorten breeding period and breed varieties with stress tolerance (Zhuo et al. 2007). Although genetic transformation protocols are now available for some fruit tree species, the protocols are applicable within each species to only a few genotypes that can regenerate in vitro at high frequency. Several reports concerning the transformation of apple (Malus $x$ domestica Borkh.) using Agrobacterium tumefaciens are now available (De Bondt et al. 1994; Maximova et al. 1998; Welander et al. 1998; Liu et al. 2001; Zhu et al. 2001; Igarashi et al. 2002). However, literatures on genetics transformation of $M$. zumi are limited, and optimum conditions for shoot regeneration of $M$. zumi have not yet been elucidated. On the other hand, genetics modification on apple or pear for improving the stress tolerance may result in decreasing the fruit quality. Grafting the apple scion on a transgenic $M$. zumi rootstock not only can increase the stress tolerance, but also do not reduce the fruit quality. The objective of the investigation reported here was to produce transformed $M$. zumi using the leaf explants from mature plants by optimizing the growth regulators and carbon source, in a particularly efficient regeneration procedure using the nptII gene and screening with kanamycin. Our results show that using fructose instead of sucrose significantly increases the shoot regeneration and decreases vitrification, and ex vitro rooting of microcuttings reduces the time for establishment and improves the survival rate of transgenic plantlets.

\section{MATERIALS AND METHODS}

\section{Plant materials and tissue culture}

Leaf explants were obtained from 2-year-old plants. The young leaves were first treated with $70 \%$ ethanol for $1 \mathrm{~min}$ and were then immersed in $0.1 \%$ mercuric chloride for a further $8 \mathrm{~min}$, rinsed five times with sterile distilled water and then cut transversally in 2-3 mm fragments. The sterilized explants were placed horizontally, abaxial side up, on IDM medium (Table 1) for 14 days in the dark, then transferred to the same medium under the light until the shoots were regenerated from the leaf callus.

\section{Antibiotic sensitivity of explants}

To test the effectiveness of kanamycin in selecting transformants, leaf segment explants were cultured on IDM medium, supplemented with kanamycin $(15,20,30,40,50$, $60,70,80,100 \mathrm{mg} \mathrm{l}^{-1}$ ). After 4 weeks, the callus formation and adventitious shoots were counted and regeneration frequencies were determined.

\section{Transformation, selection and plant regeneration}

For transformation experiments, leaf explants were precultured on IDM medium for 24 hrs before infection with A. tumefaciens strain EHA105 carrying the plasmid pBI121 (Figure 1). pBI121 is a binary vector that contains a kanamycin- resistant gene and an intron-containing $\beta$ -

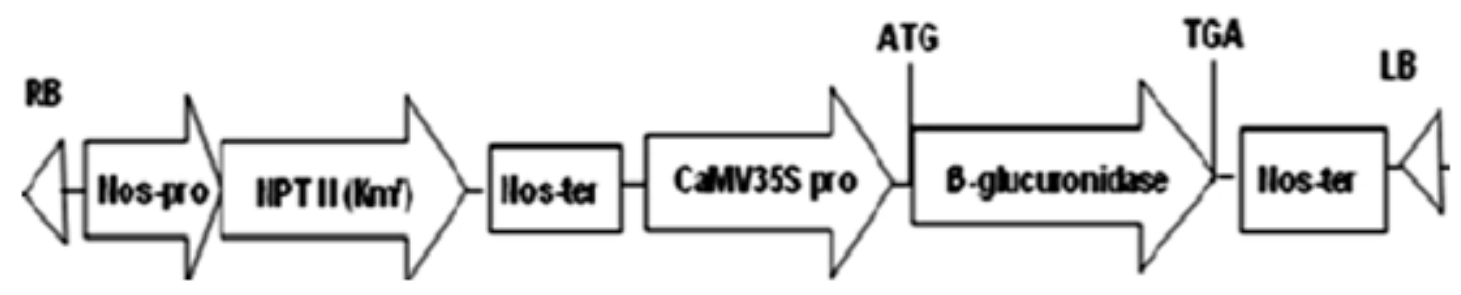

Figure 1. Schematic diagram of a part of the T-DNA region of transformation vector pBI121. RB, right border; LB, left border; Nospro, nopaline synthase promoter; NPTII, gene for neomycin phosphotransferase; NOS-ter, terminator of nopaline synthase; CaMV35Spro, 35S promoter of cauliflower mosaic virus; $\beta$-glucuronidase, GUS reporter gene. 


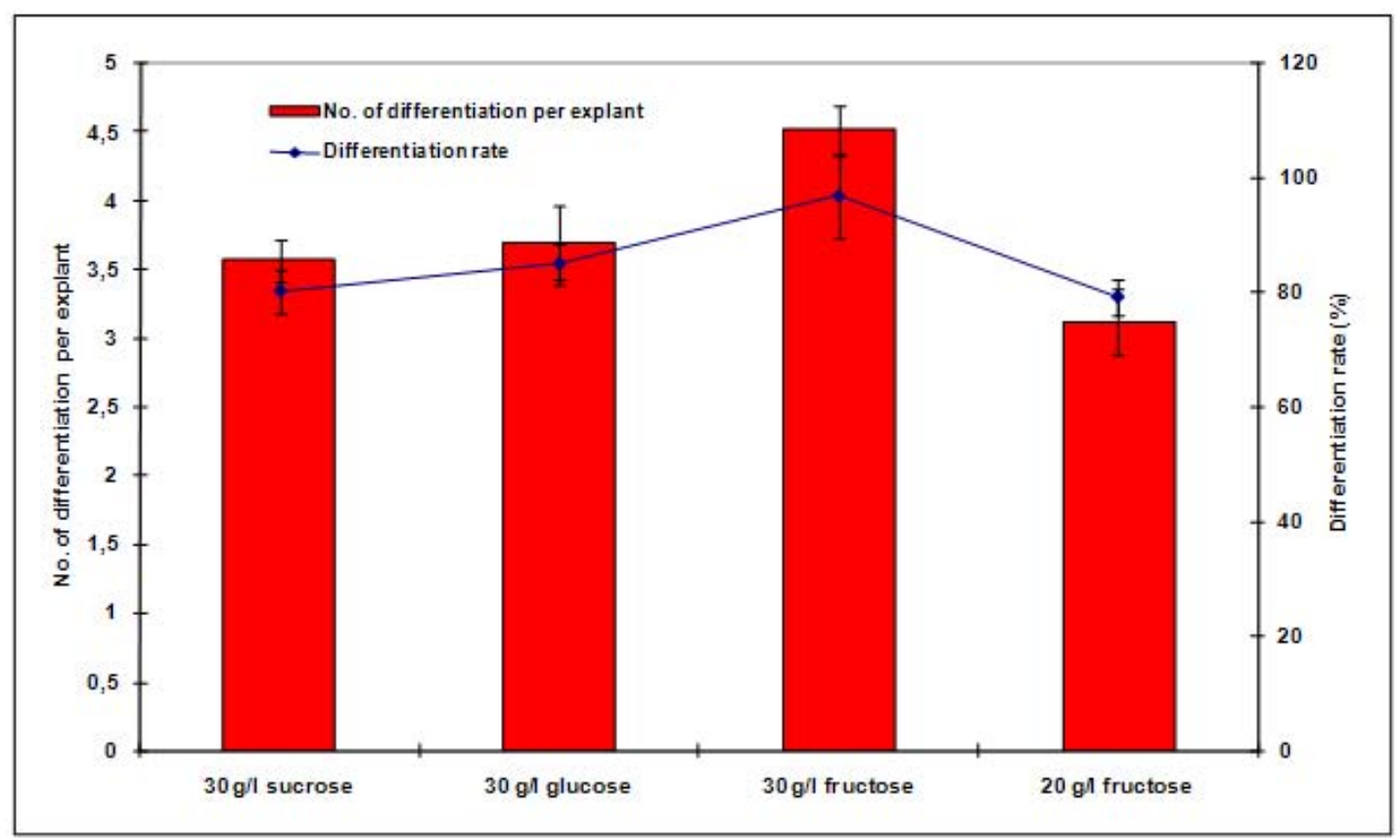

Figure 2. Effects of different carbon source on in vitro shoot regeneration of $M$. zumi after 6 weeks of culture on agar MS medium containing $3.0 \mathrm{mg} \mathrm{l}^{-1} \mathrm{BA}, 0.2 \mathrm{mg} \mathrm{l}^{-1} \mathrm{NAA}$ after 6 weeks of culture.

glucuronidase (gus) reporter gene. Overnight culture of $A$. tumefaciens having an OD of 0.8-1.0 was diluted 1:10 with liquid MS medium without plant growth regulators. The leaf explants were immersed in bacterial suspension for 10 min with constant shaking. Explants were removed blotted dried with sterile filter paper to remove excess bacteria and placed on filter paper on the same medium, the plates were sealed with parafilm and co-cultivation was carried out at $25^{\circ} \mathrm{C}$ for 1-6 days in the dark. The infected cultures were washed with MS liquid medium containing $250 \mathrm{mg} \mathrm{l}^{-1}$ carbenicillin to stop the growth of A. tumefaciens attached to the explants and then transferred to IDM-Cb medium for 0-6 day pre-selection in the dark. After pre-selection, the leaf explants were transferred to selection medium (IDM$\mathrm{Km})$ for 14 days in the dark and then transferred to light conditions $\left(40 \mu \mathrm{mol} \mathrm{m} \mathrm{m}^{-2} \mathrm{~s}^{-1}\right)$ under a 16/8-hrs (light/dark) photoperiod. Explants were subcultured onto fresh medium every 20 days. Well-developed shoots, $35-50 \mathrm{~mm}$ in length, were rooted ex vitro by a 2-hrs-treatment with aqueous solution containing MS salts and $100 \mathrm{mg} \mathrm{l}^{-1}$ IBA prior to their planting in growing substrate composed of soil and vermiculite (1:1 v/v) (Xu et al. 2008).

\section{GUS assay}

Transient histochemical GUS activity was initially assessed in transformed $M$. zumi callus. GUS expression of the leaves of putative transformants was determined. Plant tissues were incubated into GUS buffer (Jefferson et al. 1987) with the substrate $1 \mathrm{mM} \mathrm{X-Gluc} \mathrm{(5-bromo-4-chloro-}$ 3-indolyl- $\beta$-D-glucuronic acid cyclohexyl-ammonium, Sigma) at $37^{\circ} \mathrm{C}$ from 2 hrs to overnight. Stained tissues were washed and placed in $75 \%(\mathrm{w} / \mathrm{v})$ ethanol before examining under the microscope (Olympus IX71, Japan).

\section{PCR analysis and Southern blot analysis}

Genomic DNA was extracted from leaf tissues of transgenic plants and untransformed control plant according to CTAB method (Chaudhry et al. 1999). For PCR analysis of transgenic plants, the nptII gene (710 bp; amplified with primers: 5' TGCGCTGCGAATCGGGAGCG 3', 5' GAGGCTATTCGGCTATGACT 3') and gus gene (900 bp; amplified with primers 5'CGACGGCCTGTGGGCATTCA-3', 5'TGGTCGTGCACCATCAGCAC-3') were respectively employed. PCR was conducted in $0.2 \mathrm{~mL}$ thin-walled tubes in a MJ Research Minicycler. The reaction mixture, in a total volume of $25 \mu \mathrm{l}$, contained $1 \mathrm{x}$ reaction buffer, $10 \mathrm{mM}$ dNTP mixture, $5 \mu \mathrm{M}$ each primer, $0.5 \mu \mathrm{l}$ of Taq polymerase and $10 \mathrm{ng}$ of the template DNA. The reaction volume was made up to $25 \mu \mathrm{l}$ using sterile $\mathrm{dH}_{2} \mathrm{O}$. The PCR cycling conditions included an initial denaturation step of $94^{\circ} \mathrm{C}$ for $2 \mathrm{~min}$. This was followed by 30 cycles with denaturation at $94^{\circ} \mathrm{C}$ for $30 \mathrm{sec}$, annealing at $50^{\circ} \mathrm{C}$ for $30 \mathrm{sec}$ and elongation at $72^{\circ} \mathrm{C}$ for $45 \mathrm{sec}$. A final extension step at $72^{\circ} \mathrm{C}$ for $7 \mathrm{~min}$ was included. PCR products were electrophoresed on an agarose gel, stained in ethidium bromide and the DNA visualised under ultraviolet light (Sambrook et al. 1989). 
Table 1 Composition of medium in transformation experiment.

\begin{tabular}{|c|c|}
\hline Medium & composition \\
\hline IDM & MS $+500 \mathrm{mg} \mathrm{I}^{-1} \mathrm{LH}+1 \mathrm{mg} \mathrm{I}^{-1}$ Riboflavin $+30 \mathrm{gl}^{-1}$ Fructose $+7 \mathrm{gl}^{-1}$ Agar+3 $\mathrm{mg} \mathrm{l}^{-1} \mathrm{BA}+0.2 \mathrm{mg} \mathrm{I}^{-1} \mathrm{NAA}$ \\
\hline IDM-Cb & $\begin{array}{l}\text { MS }+500 \mathrm{mg} \mathrm{l}^{-1} \mathrm{LH}+1 \mathrm{mg} \mathrm{l}^{-1} \text { Riboflavin }+30 \mathrm{~g} \mathrm{l}^{-1} \text { Fructose }+7 \mathrm{gl}^{-1} \mathrm{Agar}+3 \mathrm{mg} \mathrm{l}^{-1} \mathrm{BA}+0.2 \mathrm{mg} \mathrm{l}^{-1} \\
\text { NAA }+250 \mathrm{mg} \mathrm{l}^{-1} \text { carbenicillin }\end{array}$ \\
\hline IDM-Km & $\begin{array}{l}\text { MS }+500 \mathrm{mg} \mathrm{l}^{-1} \mathrm{LH}+1 \mathrm{mg} \mathrm{l}^{-1} \text { Riboflavin }+30 \mathrm{gl}^{-1} \text { Fructose }+7 \mathrm{gl}^{-1} \text { Agar }+3 \mathrm{mg} \mathrm{l}^{-1} \text { BA }+0.2 \mathrm{mg} \mathrm{l}^{-1} \\
\text { NAA }+250 \mathrm{mgl}^{-1} \text { carbenicillin }+50 \mathrm{mgl}^{-1} \text { kanamycin }\end{array}$ \\
\hline
\end{tabular}

For Southern blot analysis of transgenic plants, genomic DNA samples were digested overnight with BamHI and separated by electrophoresis on a $1.2 \%$ agarose gel, denatured and blotted onto a nylon membrane (Roche, USA). Southern blot was hybridized with guscDNA (amplified with primers 5'CGACGGCCTGTGGGCATTCA-3', 5'-
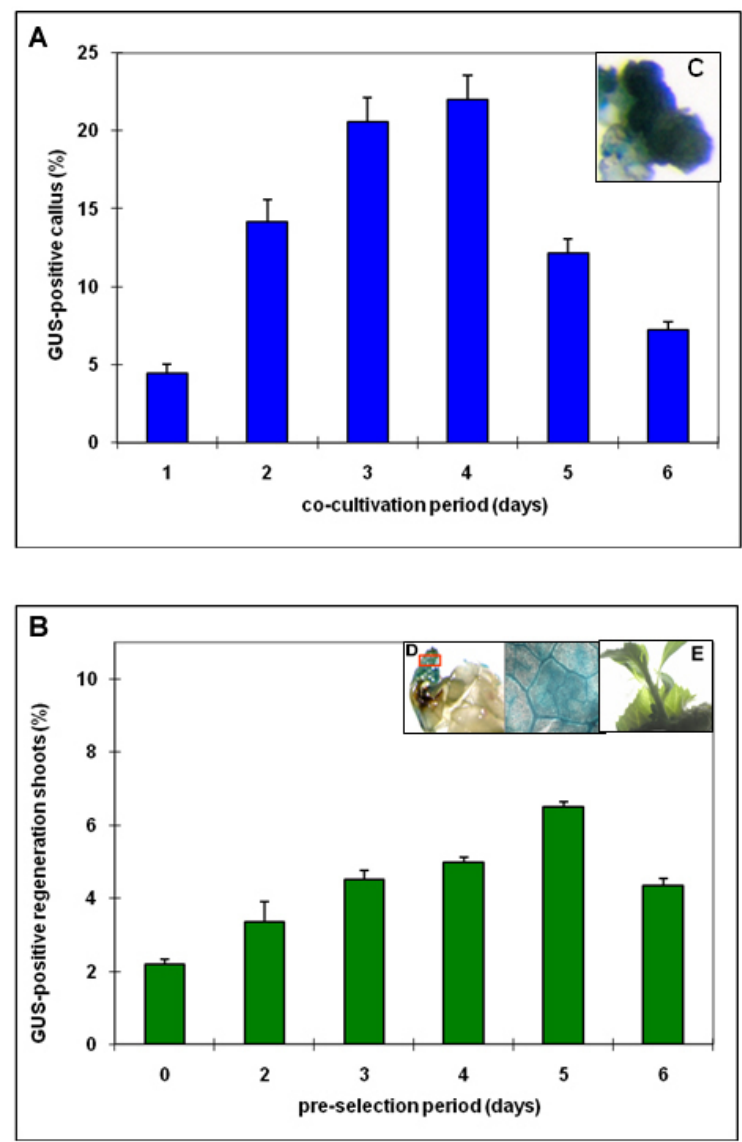

Figure 3. Effects of co-cultivation (A) and pre-selection (B) on the transformation efficiency of M. zumi. Histochemical GUS assays were performed on the transformed callus (C) and the leaf of transgenic plantlet (D). (E) Regeneration plantlet from the callus of leaf explant. Error bars represent \pm standard error $(n=3)$.
TGGTCGTGCACCATCAGCAC-3') labeled with DIGdUTP as a probe according to the protocol of the DIG High Prime DNA labeling and detection starter Kit I (Roche, USA).

Each experiment was repeated at three times in $9 \mathrm{~cm}$ petri dishes with 6 explants per dish and the significance of the results obtained for regeneration rate and transformation efficiency were verified by Duncan's test $(P<0.05)$.

\section{RESULTS AND DISCUSSION}

\section{Callus initiation and shoot regeneration}

Explants cultivated on a hormone-free medium did not dedifferentiate and gradually died during the first month in culture. Callus tissue began to appear about 14 days after the onset of the cultures and there were marked differences resulting from both composition and concentration of the hormones used (Table 2). Callus production was observed in all the treatments and callus size showed positive correlation with the concentration of NAA and BA, especially NAA. The callus formed was thick and prolific. 2,4-D promoted the callus formation and growth significantly but was not helpful for shoot differentiation due to a high rate of vitrification (data not shown). Callus formation was a prerequisite for shoot formation while callus size was not coincided with shoot formation. This has also been observed in previous studies and, as described by Matiru and Dakora (2005), callus with bigger size didn't show more shoot differentiation. A regeneration frequency of $80 \%$ was recorded producing up to 3.6 shoots per explant cultured on medium supplemented with $3 \mathrm{mg} \mathrm{l}^{-1} \mathrm{BA}$ and $0.2 \mathrm{mg} \mathrm{l}^{-1}$ NAA by the end of the $5^{\text {th }}$ week (Figure 3a). The growth and survival of cultures mainly depend on addition of carbohydrate to the medium. In general, it can serve as an osmotic agent and carbon source in the medium. According to the results, the best callus differentiation occurred with $30 \mathrm{~g} \mathrm{l}^{-1}$ fructose (Figure 2). Using fructose instead of sucrose increases the shoot regeneration and decreases vitrification. A possible explanation was that high sucrose level in the culture medium might result in chlorophyll degradation (Fernández et al. 1999). 

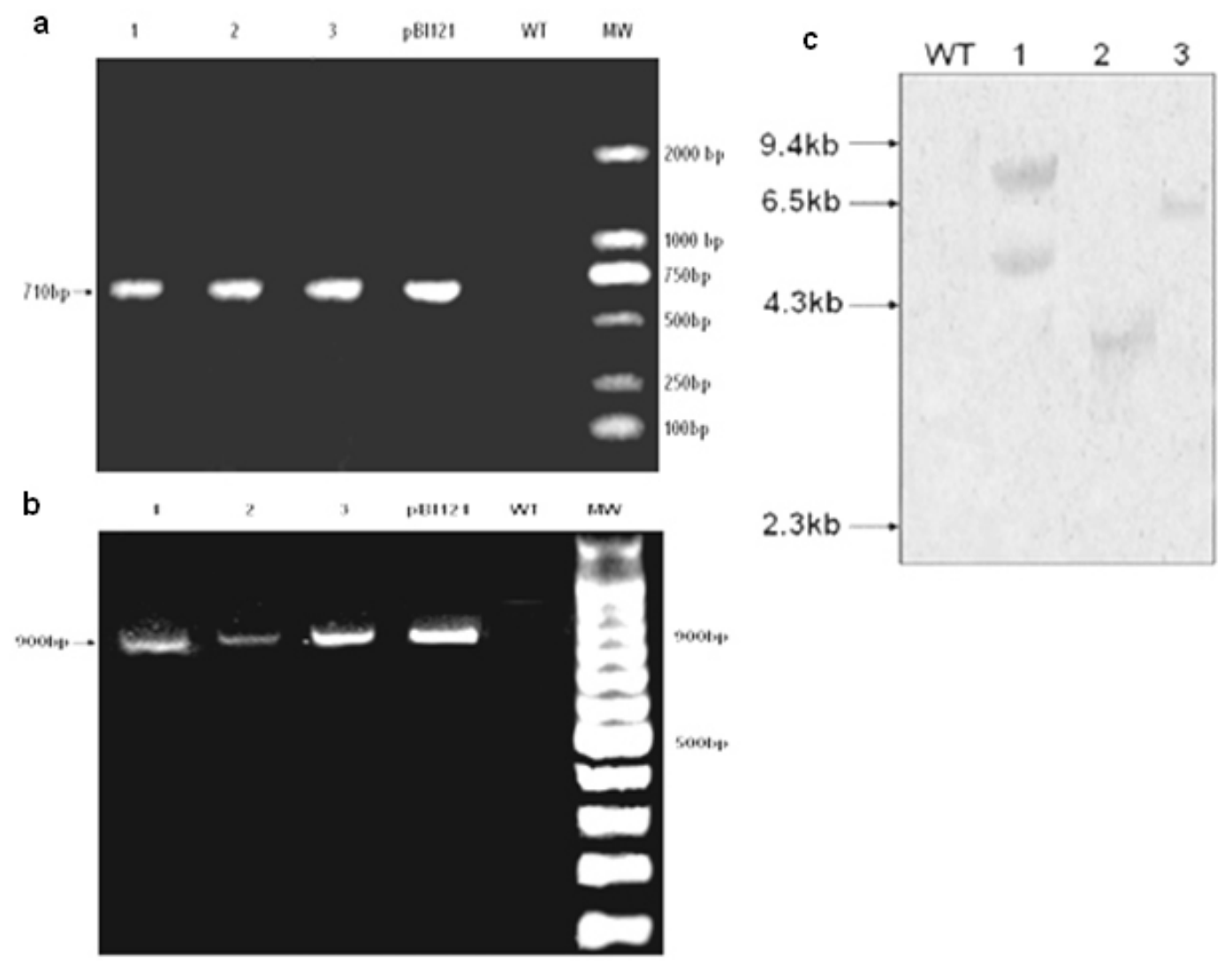

Figure 4. PCR analysis to detect the presence of nptllgene (a) and gus gene (b) and Southern blot analysis to detect the presence of gus gene (c) in transgenic plants (Lanes 1-3). WT, wild-type plant.

\section{Kanamycin sensitivity of explants}

To develop a selective growth system for genetically transformed $M$. zumi, the effects of kanamycin at various concentrations were studied. Leaf explants were precultured on IDM for 7 days before its being transferred to the same medium containing various concentration of kanamycin. There was an enormous growth of callus and almost $100 \%$ shoot regeneration on the medium without kanamycin, but no callus growth or shoot regeneration on the medium with $50 \mathrm{mg} \mathrm{l}^{-1}$ or higher concentration of kanamycin. Therefore, selection by kanamycin at $50 \mathrm{mg} \mathrm{l}^{-1}$ was used and beginning after pre-selection, and maintained till the shoots obtained.

\section{Optimization of conditions for transformation and plant regeneration}

Leaf explants were infected as described in "materials and methods". Co-cultivation leads to the induction of virulence and gene transfer, and therefore, is an essential step for $A$. tumefaciens transformation. After co-cultivation, transient GUS expression could be observed from M. zumi callus (Figure 3c). As shown in Figure 3a, although there was no significant difference between 3 and 4 days of cocultivation for $M$. zumi callus, 4 days of co-cultivation caused overgrowth of A. tumefaciens which were difficult to completely eliminate by antibiotic and therefore were harmful to the callus. Prakash et al. (1991) indicated that the co-cultivation period should be not less than 4 days, and Otani et al. (1998) indicated that 2 days was suggested for co-cultivation period. Xing et al. (2007) maintained that the difference in co-cultivation period was due to the different species and explants. In the present study, 3 days was chosen as the co-cultivation period.

After 3-day of co-cultivation, the infected cultures were washed with carbenicillin and then transferred to IDM-Cb medium for pre-selection. Pre-selection was found to be unnecessary and was mostly dependent on the target plant species that had been selected (Wahlroos et al. 2003). However, it was found that pre-selection was necessary to improve the transformation efficiency in $M$. zumi in our research. When pre-selection was omitted from the procedure, only $2 \%$ of callus initiated shoots regeneration (Figure 3b). To detection the expression of gus gene driven by $35 \mathrm{~S}$ promoter, the leaves of the transgenic plantlets were sectioned and subjected to histochemical staining. Blue staining of leaves appeared after overnight incubation in the substrate 5-bromo-4-chloro-3-indolyl- $\beta$-D-glucuronide, whereas, no histochemical staining was detected in the control callus or plants. The results showed that GUS 
Table 2. Effects of growth regulators on in vitro shoot regeneration of $M$. zumi after 6 weeks of culture.

\begin{tabular}{|c|c|c|c|}
\hline $\begin{array}{c}\text { BA } \\
\left(\mathrm{mg} \mathrm{l}^{-1}\right)\end{array}$ & $\begin{array}{l}\text { NAA } \\
\left(\mathrm{mg} \mathrm{l}^{-1}\right)\end{array}$ & $\begin{array}{l}\text { No. of differentiation } \\
\text { per explant }\end{array}$ & $\begin{array}{l}\text { Differentiation } \\
\text { rate (\%) }\end{array}$ \\
\hline 0 & 0 & $0 f^{*}$ & $0 \mathrm{~g}$ \\
\hline 1 & 0 & Of & $0 \mathrm{~g}$ \\
\hline 1 & 0.1 & $0.1 \mathrm{e}$ & $4.5 f$ \\
\hline 1 & 0.2 & $0.4 \mathrm{~d}$ & $6.4 \mathrm{e}$ \\
\hline 1 & 0.3 & $0.6 \mathrm{~cd}$ & $9.3 c$ \\
\hline 2 & 0 & $0.4 \mathrm{~d}$ & $4.4 f$ \\
\hline 2 & 0.1 & $0.8 \mathrm{~cd}$ & $12 \mathrm{c}$ \\
\hline 2 & 0.2 & $2.6 \mathrm{~b}$ & $66.4 b$ \\
\hline 2 & 0.3 & $2.3 b$ & $69.7 b$ \\
\hline 3 & 0 & $0.8 \mathrm{~cd}$ & $7.1 \mathrm{~d}$ \\
\hline 3 & 0.1 & $1.2 \mathrm{c}$ & $13.7 \mathrm{c}$ \\
\hline 3 & 0.2 & $3.6 a$ & $80.3 a$ \\
\hline 3 & 0.3 & $3.1 \mathrm{a}$ & 77.4ab \\
\hline 4 & 0 & $1.1 \mathrm{c}$ & $8.5 \mathrm{~cd}$ \\
\hline 4 & 0.1 & $1.9 \mathrm{bc}$ & $65.8 b$ \\
\hline 4 & 0.2 & $3 a$ & $72.2 b$ \\
\hline 4 & 0.3 & $3.3 a$ & $69.8 b$ \\
\hline
\end{tabular}

${ }^{*}$ Different letters in the same column indicate significant differences, $5 \%$ level, Duncan's multiple range test.

expression was active in transformed plantlets (Figure 3d; Figure 3e). The optimal transformation efficiency was obtained with 3 days of co-cultivation followed by 5 days of pre-selection.

$\beta$-glucuronidase-expressing putative transformants, 30-50 $\mathrm{mm}$ in length, were rooted ex vitro by a 2 hrs treatment with aqueous solution containing MS salts and $100 \mathrm{mg}$ $\mathrm{I}^{-1} \mathrm{IBA}$ prior to their planting in growing substrate composed of soil and vermiculite (1:1, v/v) according to $\mathrm{Xu}$ et al. (2008). The result indicated that the auxin-dipped $e x$ vitro rooting of microcuttings showed the reduced time for establishment and a better survival rate and development of transgenic plantlets.

\section{Molecular analysis of transgenic plants}

To confirm the presence of the gus gene and nptII gene in the kanamycin- resistant colonies, PCR amplification was performed on genomic DNA from 3 randomly selected putative transformants. Using the gus primers and the nptII primers, the PCR products of the expected size (720 bp for gus gene and 900 bp for $n p t I I$ gene) were amplified from 3 putative transformants and no DNA amplification was detected in the samples from the control plants, thus demonstrating that the kanamycin-resistant colonies contained the nptII gene (Figure 4a) and the gus gene (Figure 4b).

To ensure the insertion of the gus gene into the $M$. zumi genome in each transgenic line, the genomic DNA of the transgenic plants that were nptII-positive were digested with BamHI and hybridized with $0.9 \mathrm{~kb}$ gus probe. The nptII-positive putative transformants showed the presence of one or two bands that hybridized with the probe, indicating the integration of the gus gene into the genome (Figure 4c). There were two bands in Figure 4c marked line 1 , which suggested that the T-DNA was double-copy intergrated into plant genome. Unlike this, wild type control (WT) did not show the specific hybridization signal. Southern blot hybridizations further supported the results of PCR analysis. 
In summary, we report herein an efficient procotol for shoot regeneration and Agrobacterium tumefaciens- mediated transformation from the leaf explants for $M$. zumi. By performing a series of experiments, the validity of Agrobacterium- mediated transgenic system of M. zumi was confirmed by histochemical GUS assay, PCR analysis and Southern blot analysis. All these results confirmed the TDNA integration into the plant genome. The tissue culture and transformation protocol described in this paper are reproducible. The reduction of output of apple grown on infertile soils could be avoided by grafting the scion on a rootstock possessing stress tolerance. Therefore, it is significant to improve stress tolerance of rootstock by genetic transformation. This method will no-doubtedly help in transferring other genes of agronomical significance to this important fruit crop rootstock.

\section{REFERENCES}

CHAUDHRY, B.; YASMIN, A.; HUSNAIN, T. and RIAZUDDIN, S. Mini-scale genomic DNA extraction from cotton. Plant Molecular Biology Reporter, September 1999, vol. 17, no. 3, p. 280.

DE BONDT, A.D.; EGGERMONT, K.; DRUART, P.; DE VIL, M.; GODERIS, I.; VANDERLEYDEN, J. and BROEKAERT, W.F. Agrobacterium-mediated transformation of apple (Malus x domestica Borkh.): an assessment of factors affecting gene transfer efficiency during early transformation steps. Plant Cell Reports, July 1994, vol. 13, no. 10, p. 587-593.

FAHEEM, A.; ALAM, M. and AFASIAB, H. In vitro shoot multiplication and callus induction in Gladiolus Hybridus Hort. Pakistan Journal of Botany, April 2008, vol. 40, no. 2, p. 517-522.

FERNANDEZ, H.; BERTRAND, A.M. and SANCHEZTAMES, R. Biological and nutritional aspects involved in fern multiplication. Plant Cell, Tissue and Organ Culture, March 1999, vol. 56, no. 3, p. 211-214.

IGARASHI, M.; OGASAWARA, H.; HATSUYAMA, Y.; SAITO, A. and SUZUKI, M. Introduction of rolC into Marubakaidou (Malus prunifolia Borkh. var. ringo Asami Mo 84-A) apple rootstock via Agrobacteriurn tumefaciens. Plant Science, September 2002, vol. 163, no. 3, p. 463-473.

JEFFERSON, R.A.; KAVANAGH, T.A. and BEVAN, M.W. GUS fusions: $\beta$-glucuronidase as a sensitive and versatile gene fusion marker in higher plants. EMBO Journal, December 1987, vol. 6, no. 13, p. 3901-3907.

LIU, Q.; INGERSOLL, J.; OWENS, L.; SALIH, S.; MENG, R. and HAMMERSCHLAG, F. Response of transgenic Royal Gala apple (Malus $x$ ornestica Borkh ) shoots carrying a modified cecropin MB39 gene to Erwinia arnylovora. Plant Cell Reports, June 2001, vol. 20, no. 4, p. 306-312.
MATIRU, V.N. and DAKORA, F.D. The rhizosphere signal molecule lumichrome alters seedling development in both legumes and cereals. New Phytologist, May 2005, vol. 166, no. 2, p. 439-449.

MAXIMOVA, S.N.; DANDEKAR, A.M. and GUILTINAN, M.J. Investigation of Agrobacteriurnmediated transformation of apple using green fluorescent protein: high transient expression and low stable transformation suggest that factors other than T-DNA transfer are rate-limiting. Plant Molecular Biology, June 1998, vol. 37, no. 3, p. 549-559.

MOHAN JAIN, S. Tissue culture-derived variation in crop improvement. Euphytica, March 2001, vol. 118, no. 2, p. 153-166.

OTANI, M.; SHIMADA, T.; KIMURA, T. and SAITO, A. Transgenic plant production from embryogenic callus of sweet potato (Ipomoea batatas (L.) Lam.) using Agrobacterium tumefaciens. Plant Biotechnology, January 1998, vol. 15, no. 1, p. 11-16.

PRAKASH, C.S.; VARADARAJAN, U. and KUMAR, A.S. Foreign gene transfer to sweet potato Ipomoea batatas (L.). Hortscience, May 1991, vol. 26, no. 5, p. 492.

SAMBROOK, J.; FRITSCH, E.F. and MANIATIS, T. Molecular Cloning. A laboratory manual. ( $2^{\text {nd }}$ edition). Cold Spring Harbor; Cold Spring Harbor Laboratory Press, 1989. 2344 p.

SCHEEWE, P. and KETZEL, A. In vitro screening for resistance against powdery mildew (Podosphaera leucotricha (Ell. et Ev.) Salm.) in apple. Zeitschrift Fuer Pflanzenkrankheiten and Pflanzenschutz, December 1994, vol. 101, no. 4, p. 368-377.

WAHLROOS, T.; SUSI, P.; TYLKINA, L.; MALYSHENKO, S.; ZVEREVA, S. and KORPELA, T. Agrobacterium-mediated transformation and stable expression of the green fluorescent protein in Brassica rapa. Plant Physiology and Biochemistry, September 2003, vol. 41, no. 9, p. 773-778.

WELANDER, M.; PAWLICKI, N.; HOLEFORS, A. and WILSON, F. Genetic transformation of the apple rootstock M26 with the rolB gene and its influence on rooting. Journal of Plant Physiology, December 1998, vol. 153, no. 3-4, p. 371-380.

XING, Y.J.; YANG, Q.; JI, Q.; LUO, Y.M.; ZHANG, Y.F.; GU, K. and WANG, D.Z. Optimization of Agrobacteriummediated transformation parameters for sweet potato embryogenic callus using $\beta$-glucuronidase (GUS) as a reporter. African Journal of Biotechnology, November 2007, vol. 6, no. 22, p. 2578-2584.

XU, J; WANG, Y.Z.; ZHANG, Y.X. and CHAI, T.Y. Rapid in vitro multiplication and ex vitro rooting of $M$. 
$\mathrm{Xu}, \mathrm{J}$. et al.

zumi (Matsumura) Rehd. Acta Physiologiae Plantarum, January 2008, vol. 30, no. 1, p. 129-132.

ZHU, L.H.; HOLEFORS, A.; MHLMAN, A.; XUE, Z.T. and WELANDER, $M$. Transformation of the apple rootstock M.9/29 with the rolB gene and its influence on rooting and growth. Plant Science, February 2001, vol. 160, no. 3, p. 433-439.

ZHUO, R.Y.; QIAO, G.R and SUN, Z.X. Transgene expression in Chinese sweetgum driven by the salt induced expressed promoter. Plant Cell, Tissue and Organ Culture, January 2007, vol. 88, no. 1, p. 101-107. 